\title{
The Creation of Campus Cafe in Getting Profit
}

\author{
Fitri Hayati \\ Teaching staff at Faculty of Islamic Business Economics, State Islamic University of North Sumatera (UINSU), \\ Indonesia \\ Pipiet_hayati@yahoo.com
}

\begin{abstract}
The culinary business recently becoming trend is blocked by people. Café is a vehicle for people to gather, play and work and so on. Attractive offers are always served at Cafés ranging from food and drinks with unique variations in accordance with the café theme itself. This cafe business has become a business attraction. This is because people are more comfortable in the café for more relaxed activities. Café is also a flexible place for everyone. In addition to its convenient location, the café also often offers Free WIFI. The aim of research is to find a successful method of running a café business with limited business capital. The research method is a qualitative method. The researcher examined the success tips used by the Campus Cafe on Selamat Ketaren Street No.1 and 2, Percut Sei Tuan, Medan City, North Sumatra 20371 with the name of the owner of Sultoni's brother. This cafe is just the grief of the owner, starting from unsold merchandise until employee changes. Not infrequently also the owner suffered a loss. But now this Campus Cafe has started to develop rapidly. Its existence has begun to compensate for the cafes around Jalan Selamet Ketaren, especially the Aceh Corner, which is always crowded with customers. It operates for approximately 3 years.
\end{abstract}

Keywords : Business; culinary business; café

\section{Introduction}

Culinary business is always exist. As one of the main needs of humans, food offers a variety of business opportunities to work on. For those who have tight capital and mediocre cooking skills, selling processed food, such as fried rice, which is offered around by cart can be a viable business idea. But of course, culinary business opportunities are not limited to such a survival business. When people's purchasing power increases, the desire to enjoy food is increasingly diverse. There are people who are determined to live a healthy life so they are willing to count how many calories there are in each meal. This group of people opens a market gap for those who want to do a healthy catering business. In fact, culinary business opportunities can also come from the need for snacking, aka enjoying snacks while chatting with family or relatives. This is what gave birth to places like cafes.

Nowadays cafes are no longer a place for foreigners who live in urban areas. Cafes whose concepts come from abroad, succeed in French, reverse the place where people mingle and enjoy a variety of drinks and snacks. Indeed, the concept of coffee has equivalents here, namely coffee shops. However, if we hear the name of the coffee shop, our memories must be stumbling to the place where coffee is designed by old school. Some of today's culinary business people prefer to match the term cafe on the place name board that is needed for the term coffee shop. In addition to giving a more attractive impression to prospective buyers, the concept of the cafe is more flexible. At least, in the variety of drinks offered.

A cafe, currently developing and wants to be bought so as not to get bored, of course you can add a menu of drinks other than coffee, such as tea, or even drinks that contain alcohol. Many cafe owners currently choose coffee as a beverage menu that has the resources that have the ability there. Besides they have passion there.

The cafe is a place where many people hold meetings, enjoy enjoying a meal to unwind from the daily routine. With a comfortable space with drinks and food support, the cafe will 
be the most fun and visited by many people. Today, cafes have indeed become a phenomenon and a modern lifestyle, especially for young people. So from here the opportunity to gain profits and a large turnover from the open business cafe is very wide open. However, there are still some great opportunities. You should be able to run this cafe with several variations and precise tips for success. More if you only have minimal or limited fund.

\section{Literature Review}

\subsection{Business}

In economics, business is an organization that sells goods or services to consumers or other businesses, to make a profit. Historically the business word of English business, from the word busy which means "busy" in the context of individuals, communities, or society. In a sense, busy working on activities and jobs that bring profit. In a capitalist economy, where most businesses are owned by the private sector, businesses are formed to profit and increase the prosperity of their owners. The owner and operator of a business gets rewards according to the time, effort, or capital they provide. However, not all businesses pursue such benefits, such as cooperative business that aims to improve the welfare of all its members or government institutions aimed at improving people's welfare. This business model contrasts with the socialistic system, where large businesses are mostly owned by the government, the general public, or trade unions.

Etymologically, business means a situation where a person or group of people is busy doing a job that produces profit. The word "business" itself has three uses, depending on the scope - the use of singular business words can refer to business entities, namely juridical (legal), technical, and economic unity which aims to seek profit or profit. Wider use can refer to certain market sectors, such as "television business." The most extensive use refers to all activities carried out by the community providing goods and services. But the definition of the right "business" is still a matter of debate to date.

Although the form of business ownership varies by country, there are several forms that are considered common:

\section{a. Individual company}

An individual company is a business whose ownership is held by one person. Owners of individual companies have unlimited liability for company property. This company is managed individually and has full responsibility for the continuity of the company and its capital comes from its own. This is usually individual company has advantages and disadvantages.

\section{b. Fellowship}

A partnership is a form of business where two or more people work together to operate a company to make a profit. Just like an individual company, every ally (member of a partnership) has unlimited liability for the company's assets. Guild can be grouped into a limited partnership and the firm.

\section{c. Company}

The company is a business whose ownership is held by several people and supervised by a board of directors. Each owner has limited responsibility for the company's assets.

\section{d. Cooperative}

Cooperatives are businesses that have members or cooperative legal entities based on their activities based on cooperative principles as well as people's economic movements 
based on family principles. Cooperative aims to improve the life of its members. The main characteristic of cooperatives that differentiates them from other business entities is that members of cooperatives have multiple identities. Dual identity means cooperative members are owners and users of cooperative services. Businesses consist of various types, and, as a result, businesses can be grouped in different ways. One of the many ways that can be used is to classify businesses based on the activities they do in generating profits.

- Manufacturing is a business that produces products originating from raw goods or components, then sells them for profit. Examples of manufacturing are companies that produce physical goods such as cars or pipes.

- Business services are businesses that produce intangible goods, and get profits by asking for payment for the services they provide. Examples of services businesses are a consultant and psychologist.

- Retailers and distributors are parties who act as intermediaries for goods between producers and consumers. Most shops and consumer-oriented companies are distributors or retailers.

- The agriculture and mining business is a business that produces raw goods, such as mining plants or minerals.

- Financial business is a business that benefits from investment and capital management.

- The information business is a business that produces profits mainly from the saleback of intellectual property.

- Utilities are businesses that operate services for the public, such as electricity and water, and are usually funded by the government.

- The real estate business is a business that generates profits by selling, renting and developing property, houses and buildings.

- The transportation business is a business that benefits by delivering goods or individuals from one location to another.

- Online business is a business that is done online through the internet. In an online business, any item can be labeled as a business in general. To be able to do business online, many media can be utilized, one of which is a website, facebook, twitter, Instagram, path, blog and others.

\subsection{Profit}

Profit, profit, or profit can be defined in two ways. The first Profit in pure economics is defined as an increase in an investor's wealth as a result of his investment, after deducting the costs associated with the investment (including, opportunity costs). Meanwhile, profit in accounting is defined as the difference between the selling price and the production cost. Profit is the element of fire that is the most concern of the user because the profit figure is expected to be rich enough to represent the company's overall performance. However, accounting theory to date has not yet achieved stability in the meaning and measurement of profits. Therefore, in contrast to the water element of other financial statements, the discussion of earnings includes three levels, namely: semantics, syntax, and pragmatics.

Profit or Profit is the Net Difference of All Revenues and Expenses. Revenue is the income from all existing potential, either Direct or Indirect, such as Sales Results, Results of Administrative Costs, Results of Registration Fees, while Cost is a deduction factor or Costs 
incurred in connection with Organization Operations, such as Salaries, Honors, Allowances and others. Profit is Revenue - Cost, and is one indicator of the health of a Company.

\subsection{Revenue Component (Revenue)}

A Banking Financial Institution has Financial Resources from a third party other than Own Capital. What are the components of income for a financial institution such as a bank? Next you can understand some of the parameters that are Revenue:

- Interest on Loan Results

- Bond Interest in Government

- Administrative costs relating to Credit Application

- Interbank Spot Interest Fees

- And others

If you read the Financial Balance of a Bank Financial Institution, it will be clear what components become the Fuel Producer of their Organizational Life. In principle, every Interest Income that enters a Bank's Revenue and this becomes the Main Income in living the Business Wheel Turnover. There are still many income resources that might be obtained such as Insurance Product Sales Services (Bancasurrance), Transfer Services, etc.

\subsection{Cost Component (Cost)}

In addition to obtaining interest income, each organization will incur a lot of costs such as salary, allowances and others. This Note is all the Liability of each Company to the Related Party. The following are some of the Components of Expenditure (Cost):

- Capital costs (buildings, tables, chairs, etc.)

- Marketing costs

- Risk costs

- Capital Reserves

- Tax

Each Component of Income and Expenditure will be very influential in achieving Maximum Profit, which is certainly the initial calculation of how a Company (Organization) is worthy of Standing, Growing and Developing. In the end after the Close of the Year, Profit will again be distributed to Shareholders or Capital Additions.

Coffee is a drink made from steeping coffee beans and mashed into powder. Coffee is one of the commodities in the world that is cultivated by more than 50 countries. Two commonly known varieties of coffee trees are Robusta (Coffea canephora) and Arabica (Coffea arabica) coffee.

Coffee processing before it can be drunk through a long process that is from harvesting coffee beans that have been ripe either by machine or by hand and then processing coffee beans and drying before turning into coffee. The next process is roasting with varying degrees of degree. After roasting the coffee beans are ground or mashed into coffee powder before the coffee can be drunk.

History records that the discovery of coffee as a nutritious and energetic drink was first discovered by the Ethiopians in the African continent around 3000 years ago (1000 BC). Coffee then continued to grow until now it is one of the most popular drinks in the world consumed by various groups of people. [Citation needed] Indonesia itself has been able to produce more than 400 thousand tons of coffee per year. Besides its attractive taste and 
aroma, coffee can also reduce the risk of developing cancer, diabetes, gallstones, and various heart diseases (cardiovascular).

The word coffee itself originally came from Arabic: قو قوة qahwah which means strength, because initially coffee was used as a high-energy food. The word qahwah was changed to kahveh, which came from the Turkish language and later changed again to koffie in Dutch. The use of the word koffie is immediately absorbed into Indonesian into the word coffee known today.

The era of the discovery of coffee beans began around $800 \mathrm{BC}$, another opinion said $850 \mathrm{AD}$. At that time, many people in the African Continent, especially the Ethiopians, consumed coffee beans mixed with animal fat and wine to meet the body's protein and energy needs. The discovery of coffee itself happened accidentally, when the shepherd named Khalid is a "Abyssinia person" observed the herd of herdsmen who remained awake even after sunset, after eating a kind of berry. He also tried cooking and eating it. This habit then continued to develop and spread to various countries in Africa, but the method of presentation was still using conventional methods. It was only a few hundred years later that these coffee beans were carried over the Red Sea and arrived in Arabia with a more advanced method of presentation.

The Arabians had more progress civilization than the African nation at that time. They did not only cook coffee beans, but also boiled the juice to be taken. In the 13th century, Muslims consumed coffee as an energy-enhancing drink during worship at night. The popularity of coffee also increased along with the spread of Islam at that time to reach the regions of North Africa, the Mediterranean, and India. At this time, there was no coffee cultivation outside the Arab region because the Arabs always exported infertile coffee beans by cooking and drying them first. This causes coffee cultivation is not possible. It was only in the 1600s, an Indian pilgrim named Baba Budan managed to bring fertile coffee beans out of Mecca and grow them in various regions outside of Arabia

\section{Discussion}

The Campus Cafe is on Selamat Ketaren Street No.1 and 2, Percut Sei Tuan, Medan City, North Sumatra 20371 with the name of the owner of Sultoni's brother. This cafe has only been operating for about 3 years. During the 3-year trip, there were many joys and sorrows that the owner had gone through, ranging from unsold merchandise to employee change. Not infrequently also the owner suffered a loss. But now this Campus Cafe has started to develop rapidly. Its existence has begun to compensate for the cafes around Selamet Ketaren Street, especially the Aceh Corner, which is always crowded with customers.

Many things are done by Campus Cafe to be able to compete, including by designing the place as elegant and comfortable as possible. Presenting music that is in great demand by young people, as well as not missing out on food and beverage menus that invite equalization. Likewise, prices are designed not so expensive for young people. 
The various food menus are provided as follows:

Figure 1. Juice

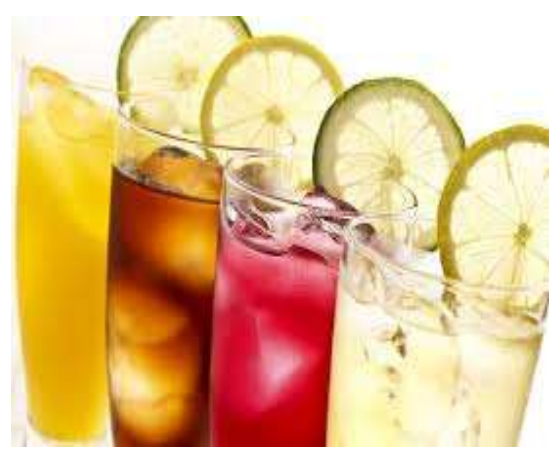

Figure 2. Fried Rice

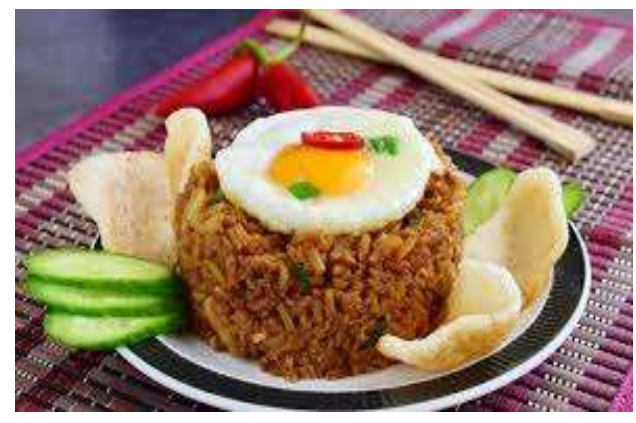

Figure 3. Penyet Chicken

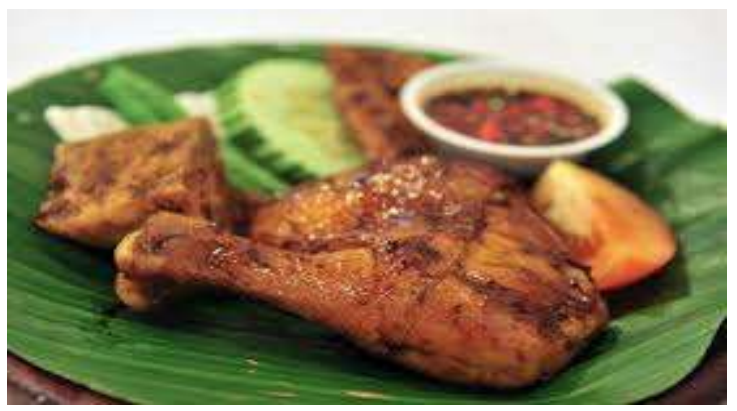

Figure 4. Bakar Fish

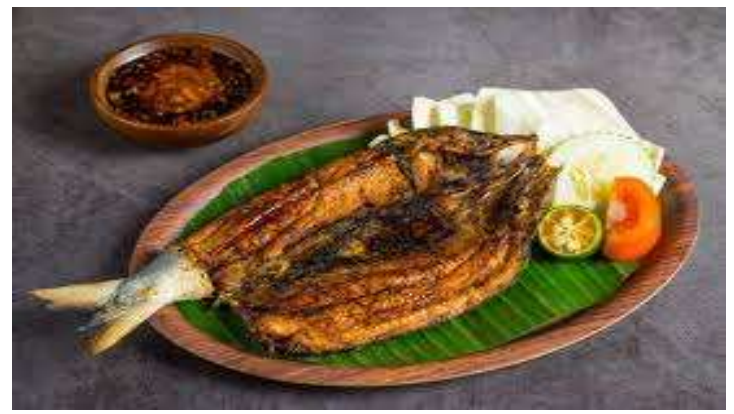


Figure 5. Lele Penyet

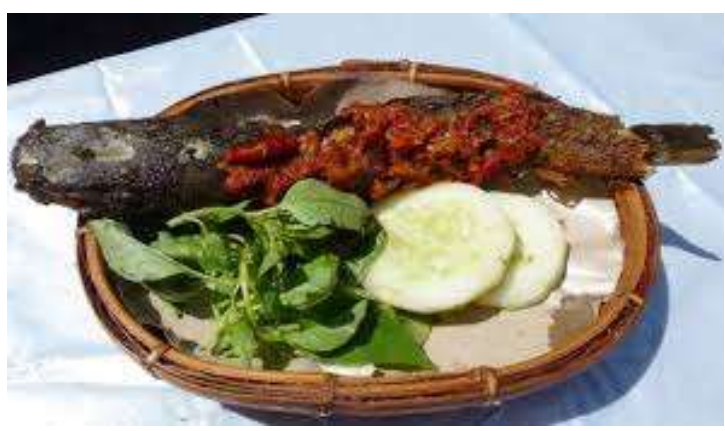

\section{Conclusion}

The café business trip carried out by Sultoni under the Campus Cafe label is very proud because from some of the cafes in Medan, especially those around Selamet Ketaren street, this cafe is one that is able to survive and is able to generate many benefits. With the location surrounded by well-known campuses, finally this cafe can exist in the midst of similar business activities carried out by other people. The elegant menu display and service display can erode the initial notion that this cafe will not advance.

\section{References}

Achmad Ali, Wiwie Heryani,. 2012. Menjelajahi Kajian Empiris Terhadap Hukum. Jakarta: Kencana.

Agus Arijanto, 2011. Etika Bisnis Bagi Pelaku Bisnis, Jakarta: Raja Grafindo Persada. Ahmadin.2013. Metode Penelitian Sosial. Makassar: Rahyan Intermedia.

B.F. Skinner, 2013. Ilmu Pengetahuan Dan Perilaku Manusia (Science and Human Behavior), Yogyakarta: Pustaka Pelajar.

Francis Tantri. 2009. Pengantar Bisnis. Jakarta: Raja Grafindo Persada.

Galuh Puspaningrum. 2013. Hukum Persaingan Usaha. Yogyakarta: Aswaja Pressindo.

Hadikusuma, Hilman. 2004. Pengantar Antropologi Hukum. Bandar Lampung: Citra Aditya Bakti.

Hasrullah.(Skripsi).2005. Eksistensi Usaha Kafe Di Kota Makassar (Tinjauan Antropologis). Jurusan Antropologi. Fakultas Ilmu Sosial dan Ilmu Politik, Universitas Hasanuddin.

Kamal Rokan, Mustafa. 2012. Hukum Persaingan Usaha. Jakarta: Raja Grafindo Persada.

Koentjaraningrat. 2009. Pengantar Ilmu Antropologi. Jakarta: Rineka Cipta.

Philip Kotler, Swee Hoon Ang, a.1, Manajemen Pemasaran Sudut pandang Asia, Singapura: Indeks.

Rama Fanny.(Skripsi), 2008. Analisis Sikap Dan Faktor-Faktor Yang Mempengaruhi Keputusan Kunjungan Konsumen Kafe Baca Di Buku Kafe, Depok Jawa Barat. Faculty of Agriculture. Institut Pertanian Bogor.

Zainuddin Ali. 2014. Antropologi Hukum. Jakarta Selatan: Yayasan Masyarakat Indonesia Baru. 